\title{
THE HISTORY OF THE ANTHROPOLOGICAL ORIGIN OF THE UZBEK PEOPLE
}

\author{
Khakima Davlatova
}

Researcher Jizzakh State Pedagogical Institute Jizzakh, Uzbekistan

Dilfuza Davurboyeva

Researcher Jizzakh State Pedagogical Institute Jizzakh, Uzbekistan

Maftuna Lapasova

Researcher Jizzakh State Pedagogical Institute Jizzakh, Uzbekistan

\section{ABSTRACT}

This article discusses the ethnographic history of the Uzbek people. The same picture is observed in the composition of the Uyghur ethnic group. For example, not only modern Uyghurs, but also Uzbeks, Kazakhs, Kirghiz, etc. were formed from the Uyghur ethnic group. The same can be said about written records. Evaluation of the role of each of these disciplines as a source of ethnogenetic and ethno-historical information, the need for complexity, synthesis of developments in various sciences have been repeatedly discussed.

KEYWORDS: - Ethnographic history, history of Uzbek people, composition of Uyghur, ethnic group, modern Uyghurs, Uzbeks, Kazakhs, Kirghiz, written records, a source of ethnogenetic, ethno-historical information.

\section{INTRODUCTION}

The largest nation in Central Asia, they are the main and indigenous population of Uzbekistan, quite large groups of autochthonous Uzbeks live in northern Afghanistan, northwestern, northern, western Tajikistan, southern Kazakhstan, southern Kyrgyzstan, northern and eastern Turkmenistan. Ethnogenesis of Uzbeks proceeded in Movaraunnahr and adjacent regions. The ancient peoples of Central Asia, Sogdians, Bactrians, Khorezmians, Ferghans, Sako-Massaget tribes, eastern Iranians, and Hephthalites, took part in the formation of the Uzbeks. In the VIII-II century BC. Central Asia was inhabited by Scythians (according to Greek sources), or Saki (according to Persian sources), Massagets and Sogdians, Khorezmians and other ethnic groups.

In general, the Turkic-Mongol tribes that roamed in the second half of the XIV century. in the eastern part of Dashti Kipchak, they were called Uzbeks, and their territory was the land of Uzbeks. After their conquest in the first half of the 15th century. The local population of Maverannahr also began to be called Uzbeks. It should be noted that the ancient clans of Saks, Massagets, Sogdians, Khorezmians and Turks, as well as other ethnic groups that joined them a little later, formed the basis for the formation of 
CURRENT RESEARCH JOURNAL OF HISTORY 2(7): 15-20, July 2021

DOI: https://doi.org/10.37547/history-crjh-02-07-04

ISSN 2767-472X

(C)2021 Master Journals

\section{Crossref do) 11 Google}

Accepted 08 ${ }^{\text {th }}$ July, 2021 \& Published 13 $3^{\text {th }} J u l y, 2021$

Uzbeks, Kazakhs, Kirghiz, Karakalpaks, Uighurs and other Turkic peoples, they also participated in the formation of the neighboring Tajik people. It should be borne in mind that the same clans and tribes could participate in the formation of different Turkic peoples. For example, the Uzbek and Kazakh peoples include the Kipchak, Jalair, Naiman, and Katagan clans.

\section{THE MAIN FINDINGS AND RESULTS}

Therefore, the fact of the presence in the Uzbek and Kazakh languages of common phenomena inherent in the languages of the aforementioned genera should not be considered as a product of the relationship between the Uzbek and Kazakh languages of a later time. Therefore, the fact of the presence in the Uzbek and Kazakh languages of common phenomena inherent in the languages of the aforementioned genera should not be considered as a product of the relationship between the Uzbek and Kazakh languages of a later time. Summarizing what has been said, we can conclude that the domination of the ancient Turks in Central Asia covers the 5th-10th centuries, during this period, power is concentrated in the hands of the Tuku (V-VIII century), Turks of Central Asia (552-745), the Uyghur kaganate (740-840), the Uyghur state (up to the 10th century).

Frequent changes in power did not lead to any changes in the ethnic composition of the Turkic population, then living in a very large territory (in the south of Siberia, Kazakhstan, Central Asia, East Turkestan): language, customs, clothing, culture and other components of Turkic ethnic groups continued to be very skinny. As a rule, each kaganate consisted of certain ethnic groups, and each ethnic group was called the name of the most privileged clan or tribe, although it included many other clans and tribes. For example, the Karluk ethnic group included, in addition to the Karluks themselves, Chigils (mainly in
Movarounnahr) and Yagma (in the territories from the Ili River basin to Kashgar). The Yagma clan, before merging with the Karluks, was part of the Tugiaguz (Tukkiz-Oghuz) ethnic group. The same picture is observed in the composition of the Uyghur ethnic group. For example, not only modern Uyghurs, but also Uzbeks, Kazakhs, Kirghiz, etc. were formed from the Uyghur ethnic group. The same can be said about written records.

To date, extensive materials have been accumulated on the ethnogenesis and ethnic history of Uzbekistan, represented by data from various sciences - history, archeology, ethnography, anthropology, linguistics, folklore, onomastics, oriental studies, historical demography, geography, etc. Evaluation of the role of each of these disciplines as a source of ethnogenetic and ethno-historical information, the need for complexity, synthesis of developments in various sciences have been repeatedly discussed. However, in the history of the study of the ethnogenesis of the Uzbek people, a mono-ethnic approach often prevailed, the data of related sciences were not sufficiently involved, the importance of certain disciplines was absolutized, in particular, the substitution of ethnogenesis by culture genesis and glottogenesis, there was no correlation between the results of certain sciences among themselves and with political history.

Anthropology plays a significant role in the study of ethnic history, especially in illuminating the continuity of the population, identifying the direction and time of migration, the nature of the relationship between the substratum and superstrate population, interaction between neighboring and distant ethnic groups, etc. The anthropological types of individual populations are formed on the basis of the same groups of todey that peoples are ethnic groups, that is, populations are associated with ethnic groups. This position underlies all ethnogenegical 
CURRENT RESEARCH JOURNAL OF HISTORY 2(7): 15-20, July 2021

DOI: https://doi.org/10.37547/history-crjh-02-07-04

ISSN 2767-472X

(C)2021 Master Journals

\section{Crossref dof 81 Google}

Accepted 08th July, 2021 \& Published 13 ${ }^{\text {th }} J u l y, 2021$

constructions of anthropology. A huge serial material on paleoanthropology and, to a lesser extent, on somatology of Uzbekistan and Central Asia has been studied.

Multilateral studies in the latest areas of anthropology - dermatoglyphics, odontology and serology, representing effective ethnogenetic and ethnohistorical information, were carried out in Kazakhstan, Turkmenistan, partly in Kyrgyzstan, but are absent in Uzbekistan. Completed individual works on dermatoglyphics do not reflect the complexity of the ethnic composition of the Uzbeks and do not cover their main ethnoterritorial groups. In addition, there are no works carried out in the diachropic aspect, when it is possible to trace the process of the formation of an ethnos and to reveal its fate, the continuity of the population, to determine the racial typology at all chronological stages of history, to reveal the dynamics of anthropological complexes and ethnic components. application of data from various independent anthropological systems, each of which makes it possible to reveal the specificity and diversity of racial and ethno-genetic processes. The consolidation of paleoanthropology, somatology data with dermatoglyphics, odontology, serology data, carrying out a study in the diachropic aspect, matching anthropological data with ethnographic, archaeological, general historical, linguistic and written sources was carried out by the author for the first time.

The main goal is to obtain racial> eshogenetic and ethnoisgoric information by conducting a comprehensive anthropological study of the population of Uzbekistan on dermatoglyphic, odontological and paleodontological, serological programs, taking into account the complexity of its ethnic and anthropological composition, with a wide involvement of information on somatology (anthropometry and anthroposcopy) and paleoanthropology, that is, biological and historical analysis in the diachropic aspect. The range of tasks set by the author includes the following:

- Study of the normal distribution of race diagnostic signs in the main ethnic and territorial groups of Uzbekistan;

- Characterization of the geographical variability of these characters and the allocation of racial complexes;

- Racial and ethnic characteristics of modern Uzbeks with tribal stratification;

- Racial and ethnic characteristics of modern Uzbeks without a tribal structure;

- Determination of the taxonomic position of Uzbeks among the Eurasian groups at the racial level;

- Determination of the taxonomic position of the Uzbek ethnos at the ethnic level;

- Intergroup analysis of population differentiation at the territorial, ethnic levels and at the level of local and large races of humanity;

- General dynamics of Mongoloid elements in the Central Asian population;

- Dynamics of Mongoloid elements by individual geographers cultural and historical and cultural areas (Sogd, Chach, Kaktriya-Tokharistan, Fergana, ParthiaMargiana, southwestern Turkmenistan, Khorezm, Ustrushana, Semirechye, Pamir);

- Determination of the specific weight of the Mongoloid component among ethnic and territorial groups and its role in ethnic history;

- Determination of the magnitude of the australoid (skaatoriaapnoy) component in the anthropological composition of the modern population;

An objective assessment of the geographical differentiation of dermatoglyphic, odontological 
CURRENT RESEARCH JOURNAL OF HISTORY 2(7): 15-20, July 2021

DOI: https://doi.org/10.37547/history-crjh-02-07-04

ISSN 2767-472X

(C)2021 Master Journals

\section{Crossref dof 81 Google}

Accepted 08 ${ }^{\text {th }}$ July, 2021 \& Published 13thJuly, 2021

and serological characteristics is given; identified local groups and complexes; the taxonomic position of the Uzbeks among the peoples of Nvraeni has been clarified; The morphological and genetic status of modern Uzbeks was determined, but for different systems of characters. For the first time, this angropological study of the modern population was carried out according to several programs (dermatoglyphics, odontology, serology), each of which meets the requirements of a racial taxonomic classification class.

As a result of the involvement of paleoactroiological, craniological and own paleodoitological material, for the first time racial and these genetic studies were carried out in a dichronal aspect, which allowed the author to consider ethnoseneic processes and dynamics, to solve such important problems as the continuity of the population, place, time and ways of formation of the main racial and ethnic components.

Based on the analysis of their own data, the author suggested that the races of the Central Asian interfluve and the Pamir-Fergaiskaya are not identical, but are separate local races that have different ratios of the main racial components. In addition, the distribution area of these races does not coincide.

The general patterns and uniqueness of racial and ethnic processes in the historical and cultural regions of Central Asia were revealed. For the first time, the fact of the formation of supra-ethnic communities and territorial complexes among the population of the Central Asian interfluve (Sogd, Ustrushana, EaktriaTokharistan, southern Khorezm) was established. Based on the results of ethnoanthropological research, a conclusion was made about the commonality of the ethno-historical and racial roots of the peoples of Central Asia and Kazakhstan. It consists of dermatoglyph, odontological and serological materials on the main ethnic and territorial groups of the Uzbek population. In order to avoid the author's discrepancies in the methodological interpretation of the signs of the day of the comparative analysis, ethno-territorial-rhetorical groups of contiguous regions were studied. As a result of field work in 1981 - 1989. collected and studied under a single program of 48 ethnic and territorial groups with a total number of 9278 people (4626 men and 4652 women).

\section{Conclusion}

In conclusion, according to the Uzbeks, they are divided into thirty-two tayors. The generally accepted version is that the name of the people comes from the name of the Khan of the Golden Horde-Uzbekkhan (1312-1341). Rashid ad-din writes that Sultan Muhammad, nicknamed Uzbekkhan, was the son of Mingkudar, the grandson of Bukal, the seventh son of Jochi, and became the khan of the Golden Horde at the age of 13 and nomadic Uzbeks were not his subjects. The meaning of the word "Uzbek" and its origin is a source of much controversy. Basic hypotheses about the origin of the word Uzbek: The earliest mention of the word Uzbek as a personal name dates back to the 12 th century.

\section{REFERENCES}

1. Zanca, R. (2004). 'Explaining'Islam in Central Asia: an anthropological approach for Uzbekistan. Journal of Muslim Minority Affairs, 24(1), 99-107.

2. Laruelle, M. (2008). The concept of ethnogenesis in Central Asia: political context and institutional mediators (194050). Kritika: Explorations in Russian and Eurasian History, 9(1), 169-188.

3. Tishkov, V. (1995). Don't Kill Me, I'm a Kyrgyz!': An Anthropological Analysis of 
CURRENT RESEARCH JOURNAL OF HISTORY 2(7): 15-20, July 2021

DOI: https://doi.org/10.37547/history-crjh-02-07-04

ISSN 2767-472X

(C)2021 Master Journals

\section{Crossref do) 81 Google}

Accepted 08 ${ }^{\text {th }}$ July, 2021 \& Published 13thJuly, 2021

Violence in the Osh Ethnic Conflict. Journal of Peace Research, 32(2), 133-149.

4. Turaeva, R. (2015). Migration and identity in Central Asia: the Uzbek experience. Routledge.

5. Rasanayagam, J. (2006). Healing with spirits and the formation of Muslim selfhood in post-Soviet Uzbekistan. Journal of the Royal Anthropological Institute, 12(2), 377-393.

6. Zanca, R. (2003). " Take! Take! Take!" Host-Guest Relations and All that Food: Uzbek Hospitality Past and Present. Anthropology of East Europe Review, 21(1), 8-16.

7. Soatova, N. (2020). Role of Shukrat in the develorment of uzbek literature of the XX century. JSPI Scientific Publications Archive.

8. Kamoliddin, S. (2006). The notion of ethnogenesis in the Ethnic Atlas of Uzbekistan. Anthropology \& archeology of Eurasia, 44(4), 42-46.

9. Zanca, R. (2005). Believing in God at your own risk: religion and terrorisms in Uzbekistan. Religion, State and Society, 33(1), 71-82.

10. Rasanayagam, J. (2011). Informal economy, informal state: the case of Uzbekistan. International journal of sociology and social policy.

11. Ilkhamov, A. (2006). Archeology of Uzbek identity. Anthropology \& archeology of Eurasia, 44(4), 10-36.

12. Pardayev, J. (2020). Some Comments on the Social Status of the Uzbek Family in the End of the XIX Century-The First Half of the XX Century: Ahrorqul Hasanovich Pardaev, Gulchehra Ismailovna Muminova and Jaloliddin Pardaev Ahrorqul Ogli. JSPI
Scientific Publications Archive.

13. Saidahmedovna, U. D., \& Qizi, R. G. B. (2021). Beliefs About the" Tree of Life" in Uzbek Folklore. Middle European Scientific Bulletin, 8.

14. Doniyorov, A. K., \& Karimov, N. R. (2020). An Incomparable Book of a Great Scholar. Bulletin Social-Economic and Humanitarian Research, (6), 63-71.

15. Doniyorov, A., Kariev, A., Aminov, H., \& Karimov, N. (2021). The Level of Study of the Religious Image of Mavarounnahr in the IX-XII Centuries. Journal of Contemporary Issues in Business and Government, 27(1), 413-423.

16. ogli Odilov, B. A., \& Karimov, N. R. (2020). Analysis of Targeted Research in 20-30 Years of the XX Century. PalArch's Journal of Archaeology of Egypt/Egyptology, 17(6), 8887-8893.

17. Karimov, N. R. (2020). A True Successor of Great Central Asian Scholars. Journal «Bulletin Social-Economic and Humanitarian Research,(7), 62-69.

18. Karimov, N. R. (2017). Researches on the scientific heritage of hakim tirmizi in egypt. In Фундаментальные и прикладные научные исследования: актуальные вопросы, достижения и инновации (рр. 177-180).

19. Juraev, Z. M., \& Masalieva, O. M. (2020). Eleven Ahmad Pilgrimage And Seal And Flag Of Victory. The American Journal of Social Science and Education Innovations, 2(12), 43-50.

20. DAVLATOVA, K., \& NEMATOV, O. (2021). Tajiks of jizzakh oasis: traditional way of life, customs and traditions and rituals. Journal of Contemporary Issues in Business and Government, 27(3), 1324- 
CURRENT RESEARCH JOURNAL OF HISTORY 2(7): 15-20, July 2021

DOI: https://doi.org/10.37547/history-crjh-02-07-04

ISSN 2767-472X

(C)2021 Master Journals

Crossref dof 81 Google

Accepted 08th July, 2021 \& Published 13 ${ }^{\text {th }} J u l y, 2021$

1329.

21. МАСАЛИЕВА, О. М. (2021). ТАЗКИРАЛАРТАРИХИЙ МУХИМ МАНБА СИФАТИДА. In Uzbek Conference Publishing Hub (Vol. 1, No. 01, pp. 123130).

22. Masalievna, M. O. (2017). LOCAL HISTORIOGRAPHY OF BUKHARA EMIRATE AT THE END OF NINETEENTH AND EARLY TWENTIETH CENTURIES. Himalayan and Central Asian Studies, 21(4), 39. 